\title{
The Role of the Diversity of the Board of Directors in Promoting Integrated Disclosure and Social Responsibility
}

\author{
Ali Khalaf Gatea ${ }^{1}$, Haider Ali Jarad ${ }^{2}$ \\ ${ }^{1}$ Technical Institute in Nasiriya - Southern Technical University- Iraq \\ ${ }^{2}$ College of Administration and Economics, University of Karbala - Iraq \\ ali.khalaf83@stu.edu.iq( ${ }^{(1)}$ \\ haider.almasudy@uokerbalaa.edu.Iq $\left({ }^{2}\right)$
}

\begin{abstract}
The integrated Disclosure aims to provide a comprehensive picture of the performance of the organization, and because the quality of the Disclosure is a critical aspect of the integrated reports, so the research aims to show the impact of the diversity of the board of directors on the quality of the integrated reports and the promotion of the social responsibility of the organization, and to make decisions about disclosure and integration in the information provided in order to benefit from it In building integrated visions about the organization, assuming that the diversity of the board of directors has a significant relationship to the extent to which the quality of integrated Disclosure is achieved, that the most important findings of the research stipulate that the diversity of the board of directors contributes to social responsibility and integrated disclosure, and the strengthening of organizational culture and administrative practices, and the research recommends, The need to interact with the environment and the communities in which the organization operates, to enable it to provide environmental, social or ethical information, along with financial, strategic and governance information in an annual report.

Key word: Diversity, Integrated Disclosure, Social Responsibility
\end{abstract}

\section{Introduction}

The dramatic development of economic conditions highlights actual and potential shortcomings in the historical information of economic units, because they cannot meet the diverse needs of investors for information consistent with the needs of economic development, and the inability to provide stakeholders with an adequate vision, with regard to critical success factors, opportunities, risks and management plans As a more integrated perspective, this change in the business environment and the increasing complexity, as a result of the increasing need for non-financial information for economic units in light of the inability of financial reports to provide information relevant to decision-making by stakeholders, which may relate to social or environmental relations as well as cultural and cognitive diversity for the individuals working therein.

It is very important to study how the diversity of the board of directors affects the disclosure and social responsibility of the organization towards stakeholders, and how to deal with the different priorities of disclosure and confidentiality of information.

The dramatic development of economic conditions highlights actual and potential shortcomings in the historical information of economic units, because they cannot meet the diverse needs of investors for information consistent with the needs of economic development, and the inability to provide stakeholders with an adequate vision, with regard to critical success factors, opportunities, risks and management plans As a more integrated perspective, this change in the 
business environment and the increasing complexity, as a result of the increasing need for nonfinancial information for economic units in light of the inability of financial reports to provide information relevant to decision-making by stakeholders, which may relate to social or environmental relations as well as cultural and cognitive diversity for the individuals working therein. It is very important to study how the diversity of the board of directors affects the disclosure and social responsibility of the organization towards stakeholders, and how to deal with the different priorities of disclosure and confidentiality of information. Cultural differences are pervasive in social and economic environments, and have long been recognized as an essential component of organizational relationships, and the main purpose of the reports is to communicate in a concise manner how the organization's strategy, governance, performance and prospects are created in the context of its external environment to create and maintain value, in light of The inability of financial reports to no longer meet the needs and stakeholders, and the financial statements are based on historical information, as they reflect the activity in the past period, which focuses largely on capital operations, while there are other resources that contribute to success such as the expertise of employees, intellectual property and research And development, in addition to the interaction with the environment and the communities in which the organization operates, is a real necessity to enable it to provide environmental, social or ethical information, along with financial, strategic and governance information within an annual report. As a result, integrated disclosure is a logical result of developing frameworks for preparing Financial reports, to accurately reflect the full range of risks, impacts, and opportunities for an economic unit, and to provide a complete picture of its financial performance $\mathrm{E}$ by including non-financial information about environmental, social and governance performance alongside financial information, which remains of significant impact as it is part of forming a complete picture of its performance by including non-financial information about environmental, social and governance performance alongside financial information, As a result, quality is a theoretical concept that is subject to the vision of stakeholders and how to benefit from it in making decisions, and that the preparation of reports effectively requires a comprehensive approach to business management, an integrated infrastructure, including the involvement of stakeholders, and an administrative approach that places value creation as a strategic issue and one of the main objectives of the organization .

\section{Letter review}

\subsection{The Concept of Cultural Dimensions}

Many concepts of cultural dimensions were presented, each of which has justifications and trends that reflect the views of its adopters, starting with the study (Parson \& Shils), which classifies cultural patterns into ideas, symbols, and forms (Waterstraat, 2015).

While the study (Kluckhohn \& Strodtbeck) sees ) that the cultural dimensions measure the values that represent "a distinct perception by the individual of the desired qualities that affect the choice among the available methods, means, and goals of work (Fink et al, 2006).

While (Hall, 1976) sees that the cultural dimensions of societies are patterns of communication between peoples, and the group that shares the same culture, it realizes the same things, and as a result, the selective culture is formed in which they see reality and solve the problems facing them (Warner, 2013).

(Hofstede, 1983) defines cultural dimensions as the collective programming of the mind that distinguishes one group of people from another, and as a result we can use culture to define the mental groups of individuals; For the purpose of defining and assessing responsibilities (Hofstede, 2011).

However (Davis) says that cultural dimensions are: shared beliefs and values that give members of the organization meaning, and provide them with rules of behavior in their workplace, and this can be the main fact that forms the bedrock of feelings and rules related to behavior on a regular basis within the unit Economics (Adedeji, et al., 2017).

As for (Schein) he describes it as the pattern of the main assumptions, invented, discovered or developed by a particular group in learning how to deal with the problems of external adaptation and internal integration; which has worked well, enough to be considered valid, and consequently being taught to new members being the correct way to perceive, think and feel in relation to these problems, and this underscores the fact that culture paves the way for nurturing 
the behavior of working individuals from economic unity, ensuring organizational expansion and continued existence (Adedeji, et al.,2017).

And (Bodker, 1991) believes that the cultural dimensions are the system on which the routine and behavior in daily practical life is based (Ford \& Kotzé, 2005).

While (Sewell's, 1992) deals with the concept of cultural dimensions from the point of view of conflict within society, describing them as invested cultural schemes with sustainable resources, reflecting and reproducing the unevenly distributed power, and that its stability depends on the active reproduction of the meanings of the permanent conflict, and as a result it gives More power for the cultural challenge, to destabilize the institutional arrangements in the societal structure, is shared by him (Lederach), who sees that cultural dimensions are shared knowledge, and schemes created by a group of people, to realize, interpret, express and respond to social facts around them (Polletta ,1997).

(Smith) indicates in his book (Cultural Theory) that the cultural dimensions of society, which are nothing but distinct and more abstract than life itself, must be understood, because they are part of an ideal and immaterial world that often symbolizes beliefs and values, but rather is a reflection of economic forces, or distribution of power, or basic needs that overlap in all aspects and levels of social life (Waterstraat, 2015).

As for (Kirsch) he believes that cultural dimensions are a reflection of social symbols, expressing collective views and behaviors, through which strategies are formulated to respond to the problems facing society, without committing to material or immaterial boundaries, which may represent a loss from the point of view of others, but It reflects the reality of the environment to which it is associated (Adger et al, 2013).

As a result, diversity in the board of directors can be associated with improving relations with stakeholders and achieving greater transparency in the preparation of reports (Gerwanski et al, 2019), and gender diversity in business boards, increases mutual respect, professionalism and credibility in dealing with beneficiaries of services that are provided. Presented by the economic unit in the field of entrepreneurship, because of the social nature of femininity and its tendency to consensus through open dialogue (Mavin \& Grandy, 2016).

\subsection{The impact of the diversity of the board of directors on decision-making}

Several studies have emerged that have been concerned with studying the impact of cultural dimensions, perhaps the most prominent of which is the study (Barrels), which dealt with social and ethical responsibility in business and the role of cultural dimensions; In making decisions and taking into account the legal aspects, personality, national identity, and property rights, based on (moral theory) that focuses on specific actions or behaviors of the individual, or (purpose theory) which is concerned with the consequences of those actions or behaviors (Vitell, 1993)

In general, business communities cannot distance themselves from the effects of cultural dimensions, as they aim to protect their interests, and as an inevitable result of the globalization of the economy, the importance of cultural influence on management and its behavior within the economic unit has increased, as it is a reflection of its environment in which it deals, and its techniques applied in decision-making as follows:

Table (1)

Types of decision making

\begin{tabular}{ccl}
\hline $\begin{array}{c}\text { No. } \\
1\end{array}$ & $\begin{array}{c}\text { Types of decision } \\
\text { Autocratic }\end{array}$ & $\begin{array}{l}\text { decision making style } \\
\text { Use of directly available information without } \\
\text { advice } \\
\text { There is prior consultation with others, whose } \\
\text { opinions may be reflected in the decision taken } \\
\text { Consulting with others without taking their } \\
\text { opinions and suggestions } \\
\text { Evaluation of alternatives, decision-making by } \\
\text { majority } \\
\text { Evaluate the alternatives, and adopt the } \\
\text { decision in advance }\end{array}$ \\
4 & Consultative & Pseudo - Consultative \\
5 & Pseudo - Participative &
\end{tabular}




\begin{tabular}{ccc}
\hline $\mathbf{6}$ & Delegatory & Authorization to make decisions \\
Source: (Podrug, 2006). & \\
\hline
\end{tabular}

Table (1) shows the methods of decision-making according to the available information that can be adopted by the administration, as a result of the changes that have occurred in the business environment and the globalization of the economy, it is imperative to achieve successful results, in decision-making strategies, based on the analysis of the fundamental causes that stimulate markets.

Although decision-making style represents a relatively consistent pattern of cognitive and emotional responses, national culture greatly influences individual values and attitudes, and has a significant influence on decision-making style (Leng \& Botelho, 2010).

The effect of cultural dimensions in the decision-making process within the economic unit, depends on a set of values, beliefs, attitudes and behavioral patterns of the people in charge of management, which can be clarified as:

\begin{tabular}{|c|c|c|c|}
\hline \multicolumn{4}{|c|}{ Table (2) } \\
\hline \multicolumn{4}{|c|}{ The impact of cultural dimensions on decision-making } \\
\hline No. & From where : & Cultura & differences \\
\hline 1 & Problem Recognition & $\begin{array}{l}\begin{array}{l}\text { Changing } \\
\text { circumstances to solve } \\
\text { the problem }\end{array} \text { to } \\
\end{array}$ & $\begin{array}{l}\text { Some cases should be } \\
\text { accepted rather than } \\
\text { changed }\end{array}$ \\
\hline 2 & Information Search & collecting "facts" & $\begin{array}{l}\text { Gather ideas and } \\
\text { possibilities }\end{array}$ \\
\hline 3 & $\begin{array}{l}\text { Construction of } \\
\text { Alternatives }\end{array}$ & future focus & $\begin{array}{l}\text { Depending on the past, } \\
\text { present and future. }\end{array}$ \\
\hline 4 & Choice & $\begin{array}{l}\text { Individual } \\
\text { making }\end{array}$ & Collective decision? \\
\hline 5 & Implementation & Delegating responsibility & $\begin{array}{l}\text { Power of } \\
\text { management }\end{array}$ \\
\hline & (015) & & \\
\hline
\end{tabular}

Table (2) shows the mechanism of dealing with decision-making within the administration, and facing the cases that can be dealt with, by studying the cultural differences of the business environment, and how to choose between the available alternatives. As a result, decisionmaking is a process of processing information related to internal problems or situations. The administration faces, or is the result of the stakeholders' desires to make a decision based on reliable and objective information for the presented problem, which includes how to extract, display and process that information, and the way of thinking that is marketed to find solutions, as decision makers can learn and be more efficient and effective decision makers, By evaluating the risks and benefits of available options, a decision is made that compares potential losses and gains (Glazer \& Karpati, 2014).

(Hunt \& Vitell,1986) explains in his theory about the importance of cultural dimensions in the ethics of the administrative decision taken and its reflection on stakeholders, and the impact of the cultural gap between decision-makers and society, in terms of public order and personal social responsibility.

\section{Methodology}

The methodology represents a map for arranging the researcher's ideas to present the research problem, its importance and the objectives that the researcher seeks to achieve, based on scientifically formulated research or mental hypotheses, and linking them with the diagnosed problems to know the level of availability of solutions and theoretical accessibility by analyzing data or opinions that can be collected from the research sample. As a result, the process of disclosing the results of the organization's work, aims to achieve a higher level of the quality of integrated disclosure, and on the other hand shows a set of dimensions that affect the behavioral aspects, to know the effects associated with the work of the organization. Whether 
these influences are social, environmental, or internal, related to how management deals with it and make decisions, and the extent of the impact of diversity on decisions taken within the organization and its impact on the disclosure of data related to decision-making from stakeholders, as it represents one of the matters of importance to the beneficiaries of Financial reports, and as a result of the expansion of business and the economic and financial overlap of various economic activities and sectors, the financial information has become insufficient to take effective decisions with a future dimension. The research seeks to shed light on the role of the diversity of the board of directors and the selection of disclosure mechanisms. The hypotheses presented by the research are related to the problems presented and the goals to be achieved, as they are answers or suggested solutions resulting from a study of the dimensions presented by the research problem, as the research assumes the following:

H1: There is a significant relationship with statistical significance at the level (0.05) between the diversity of the board of directors and the quality of integrated disclosure.

H2: There is a significant relationship with a statistical significance at the level (0.05) between the diversity of the board of directors and the social responsibility of the organization.

H3: There is a statistically significant relationship at the level $(0.05)$ between that the business environment is affected by the diversity of the board of directors, disclosure and social responsibility of the organization.

\section{Data collection and research sample}

For the purpose of measuring the impact of the diversity of the board of directors in promoting disclosure and social responsibility of the organization from the point of view of stakeholders and other beneficiaries, a questionnaire was designed that includes (10) main axis. Distributed to the dealers in the stock market (investors, beneficiaries) of the reports issued by the organization for the purpose of forming a comprehensive picture of the role played by the culture of the board of directors in disclosing the data related to making decisions. As follows:

Table (3)

Statistics

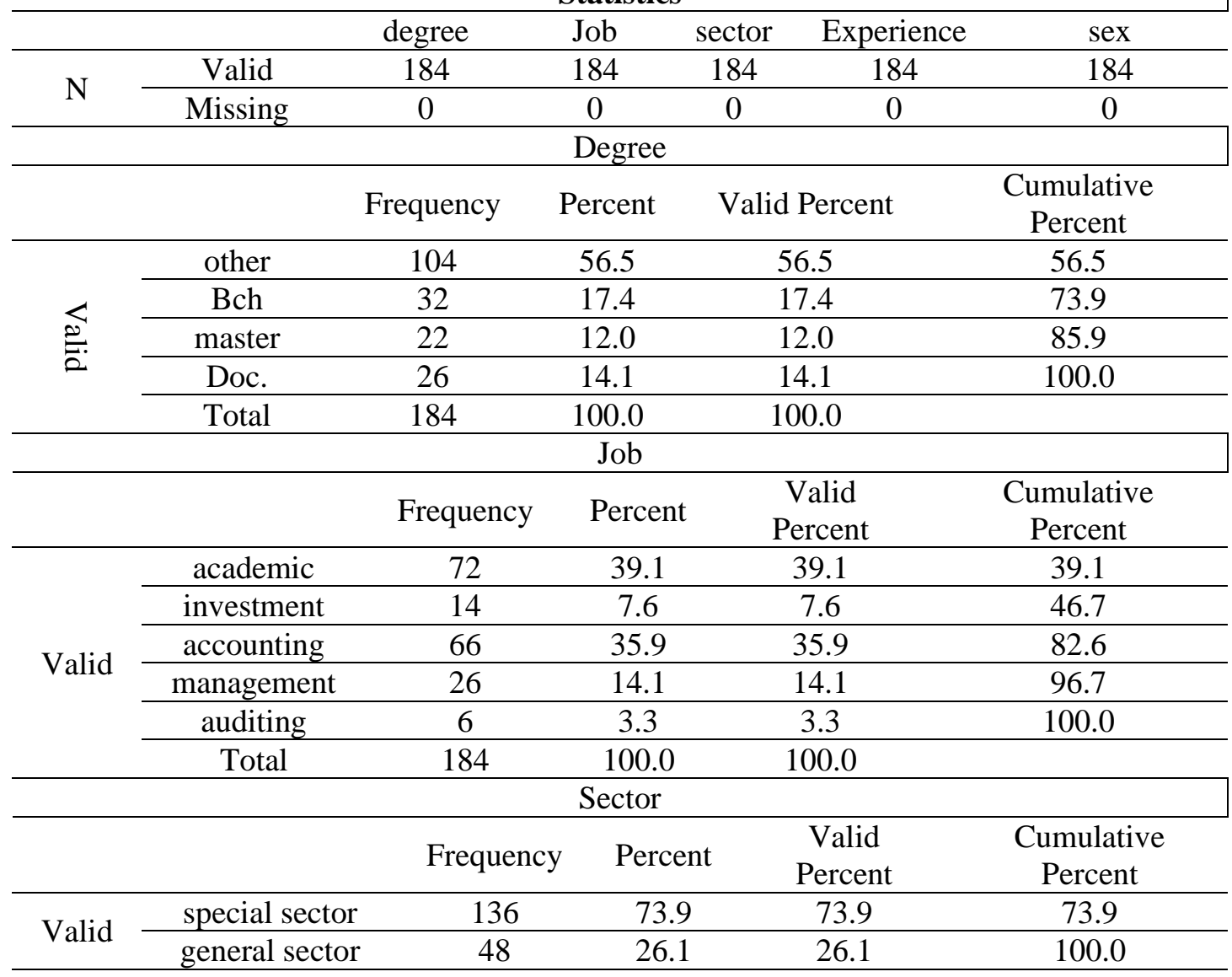




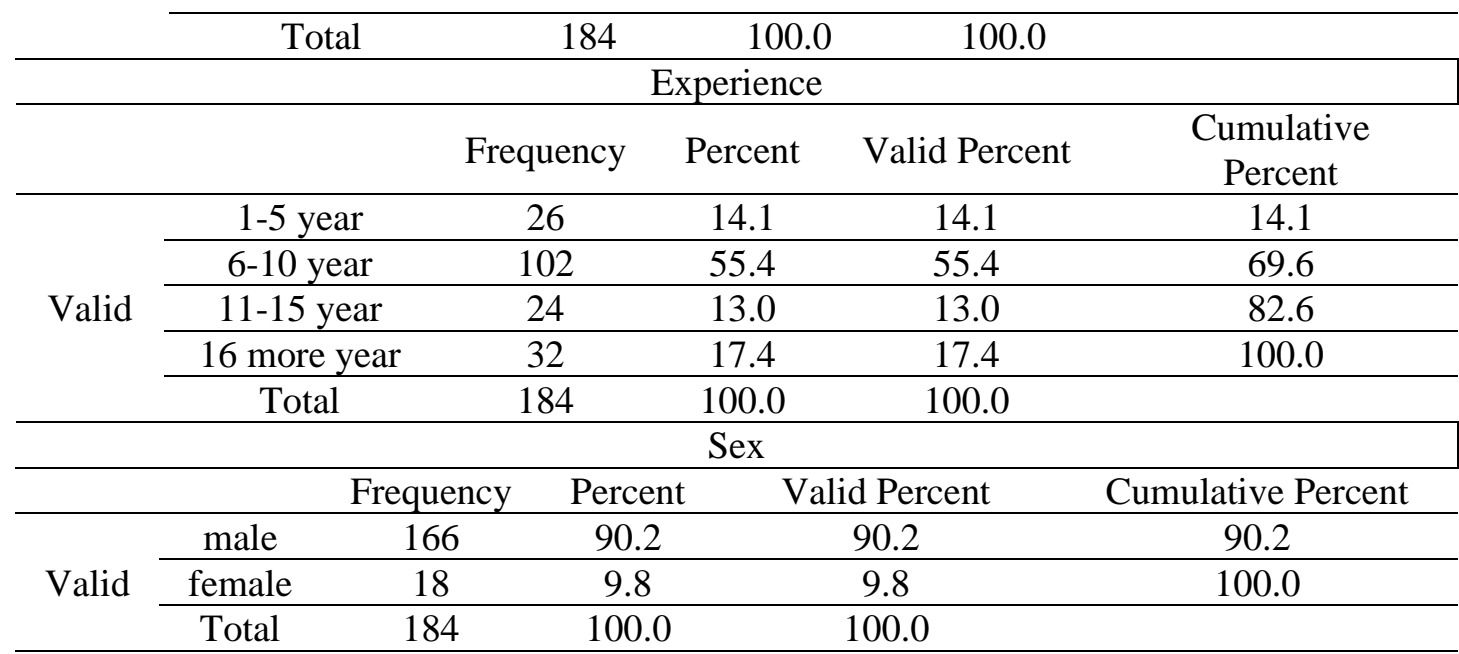

For the purpose of measuring the stability of the internal consistency between the paragraphs of the axis, the stability index (Cronbach's Alpha) was used in. Table (4)

Table (4)

Reliability Statistics

Cronbach's Alpha $\quad \mathrm{N}$ of Items

.731

10

The homogeneity of the axis paragraphs is also important in knowing the power of the questionnaire, which can be measured by the (Split-Half reliability) indicator in measuring the homogeneity and stability of the research sample. Table (5)

Table (5)

Reliability Statistics

\begin{tabular}{cccc} 
& \multirow{2}{*}{ Part 1} & Value & .602 \\
\cline { 2 - 3 } Cronbach's Alpha & & N of Items & $5^{\text {a }}$ \\
& \multirow{2}{*}{ Part 2} & Value & .713 \\
\cline { 2 - 3 } & \multicolumn{2}{c}{ N of Items } & $5^{\text {b }}$ \\
\cline { 2 - 3 } Correlation Between Forms & 10 \\
\hline \multirow{2}{*}{ Spearman-Brown Coefficient } & Equal Length & .385 \\
\cline { 2 - 3 } & Unequal Length & .556 \\
\hline Guttman Split-Half Coefficient & & .556 \\
\hline
\end{tabular}

Measure the paragraphs of the main axes Table (6)

Table (6)

\section{Descriptive Statistics}

\begin{tabular}{l|l|l|l} 
& $\mathrm{N}$ & $\mathrm{Mean}$ & $\begin{array}{c}\text { Std. } \\
\text { Deviation }\end{array}$ \\
\hline $\begin{array}{l}\text { The gender diversity of the members of the board of directors } \\
\text { affects the disclosure of integrated reports. }\end{array}$ & 3.67 & $\mathbf{1 . 0 2 5}$ \\
\hline $\begin{array}{l}\text { The gender diversity of the members of the board of directors } \\
\text { contributes to determining the priority of the objectives } 184 \\
\text { disclosed in the integrated reports. }\end{array}$ & $\mathbf{3 . 7 2}$ & $\mathbf{. 9 3 9}$ \\
$\begin{array}{l}\text { The gender diversity of the Board of Directors enhances positive } \\
\text { relations with stakeholders through the quality of integrated 184 } \\
\text { reports. }\end{array}$ & $\mathbf{3 . 8 2}$ & $\mathbf{. 8 6 1}$ \\
\hline
\end{tabular}




\begin{tabular}{|c|c|c|}
\hline $\begin{array}{l}\text { The male aspect of the board of directors dominates when } \\
\text { defining the reporting strategy in integrated reports. }\end{array}$ & 3.36 & 1.041 \\
\hline $\begin{array}{l}\text { Gender diversity on the board increases emotionality when } \\
\text { making decisions about integrated reporting. }\end{array}$ & 3.30 & 1.074 \\
\hline $\begin{array}{l}\text { Gender diversity in the board of directors leads to increased } \\
\text { societal and environmental disclosure within the integrated } 184 \\
\text { reports. }\end{array}$ & 3.68 & .922 \\
\hline $\begin{array}{l}\text { The gender diversity of the board of directors contributes to the } \\
\text { advantage of communicating with the external environment, as } 184 \\
\text { a result of disclosure in integrated reports. }\end{array}$ & 3.87 & .902 \\
\hline $\begin{array}{l}\text { Gender diversity in senior management helps make reporting } \\
\text { decisions in integrated reports to enhance future value creation. }\end{array}$ & 3.68 & .922 \\
\hline $\begin{array}{l}\text { The gender diversity in the board of directors leads to additional } \\
\text { controls in determining the priorities of disclosure in the } 184 \\
\text { integrated reports. }\end{array}$ & 3.66 & .800 \\
\hline $\begin{array}{l}\text { Gender diversity in the board of directors contributes to } \\
\text { reshaping the policy of allocating available resources in a more } 184 \\
\text { effective manner }\end{array}$ & 3.57 & 1.006 \\
\hline Valid N (listwise) & & \\
\hline
\end{tabular}

Table (6) shows the results of the axes, where the highest value was in paragraph (3), with an arithmetic mean (3.82) and a good level, while the lowest value was in paragraph (5) with an arithmetic average (3.30) and a good level.

To aprove the validity of the second sub-hypothesis, which states (there is a statistically significant relationship at the level (0.05) between the diversity of the board of directors and integrated disclosure), in terms of the relationship between the items of the first axis, which appear in Table (7) as follows:

Table (7) Correlations

The relationship between the paragraphs of the first axis

\begin{tabular}{|c|c|c|c|c|c|c|c|c|c|c|c|c|c|}
\hline & & Q1 & Q2 & Q3 & Q4 & Q5 & Q6 & Q7 & Q8 & Q9 & $\begin{array}{c}\text { Q1 } \\
\text { 0 }\end{array}$ & $\begin{array}{c}\text { Integr } \\
\text { ated } \\
\text { disclos } \\
\text { ure } \\
\end{array}$ & $\begin{array}{l}\text { social } \\
\text { responsi } \\
\text { bility }\end{array}$ \\
\hline \multirow{3}{*}{ Q1 } & $\begin{array}{c}\text { Pearso } \\
\text { n } \\
\text { Correl } \\
\text { ation }\end{array}$ & 1 & $\begin{array}{l}.19 \\
3^{* *}\end{array}$ & .21 & .15 & $\begin{array}{l}.15 \\
2^{*}\end{array}$ & $\begin{array}{l}.22 \\
1^{* * *}\end{array}$ & $\begin{array}{l}.19 \\
7^{* * *}\end{array}$ & $\begin{array}{l}.44 \\
2^{* *}\end{array}$ & $\begin{array}{l}.36 \\
1^{* *}\end{array}$ & $\begin{array}{l}.36 \\
9^{* *}\end{array}$ & $.232^{* * *}$ & $.378^{* *}$ \\
\hline & $\begin{array}{l}\text { Sig. (2- } \\
\text { tailed) }\end{array}$ & & $\begin{array}{c}.00 \\
9\end{array}$ & $\begin{array}{c}.00 \\
3\end{array}$ & $\begin{array}{c}.03 \\
4\end{array}$ & $\begin{array}{c}.04 \\
0\end{array}$ & \begin{tabular}{|c|}
.00 \\
3 \\
\end{tabular} & $\begin{array}{c}.00 \\
7 \\
\end{array}$ & $\begin{array}{c}.00 \\
0\end{array}$ & $\begin{array}{c}.00 \\
0\end{array}$ & $\begin{array}{c}.00 \\
0\end{array}$ & .002 & .000 \\
\hline & $\mathbf{N}$ & $\begin{array}{c}18 \\
4\end{array}$ & $\begin{array}{c}18 \\
4\end{array}$ & 184 & 184 & 184 & 184 & 184 & 184 & 184 & 184 & 184 & 184 \\
\hline \multirow[t]{2}{*}{ Q2 } & $\begin{array}{c}\text { Pearso } \\
\text { n } \\
\text { Correl } \\
\text { ation }\end{array}$ & $\begin{array}{l}.19 \\
3^{* * *}\end{array}$ & 1 & .23 & $\begin{array}{c}.03 \\
5\end{array}$ & $\begin{array}{l}.35 \\
4^{* *}\end{array}$ & $\begin{array}{l}.15 \\
1^{*}\end{array}$ & $\begin{array}{l}.29 \\
6^{* * *}\end{array}$ & $\begin{array}{l}.59 \\
4^{* *}\end{array}$ & $\begin{array}{l}.33 \\
3^{* *}\end{array}$ & $\begin{array}{l}.36 \\
6^{* * *}\end{array}$ & $.195^{* *}$ & $.499^{* *}$ \\
\hline & $\begin{array}{l}\text { Sig. (2- } \\
\text { tailed) }\end{array}$ & $\begin{array}{c}.00 \\
9\end{array}$ & & $\begin{array}{c}.00 \\
2\end{array}$ & $\begin{array}{c}.63 \\
6\end{array}$ & $\begin{array}{c}.00 \\
0\end{array}$ & $\begin{array}{c}.04 \\
0\end{array}$ & $\begin{array}{c}.00 \\
0\end{array}$ & $\begin{array}{c}.00 \\
0\end{array}$ & $\begin{array}{c}.00 \\
0\end{array}$ & $\begin{array}{c}.00 \\
0\end{array}$ & .008 & .000 \\
\hline
\end{tabular}




\begin{tabular}{|c|c|c|c|c|c|c|c|c|c|c|c|c|c|}
\hline & $\mathbf{N}$ & $\begin{array}{c}18 \\
4\end{array}$ & $\begin{array}{c}18 \\
4\end{array}$ & 184 & 184 & 184 & 184 & 184 & 184 & 184 & 184 & 184 & 184 \\
\hline \multirow{3}{*}{ Q3 } & $\begin{array}{c}\text { Pearso } \\
\text { n } \\
\text { Correl } \\
\text { ation }\end{array}$ & $\begin{array}{l}.21 \\
5^{* *}\end{array}$ & 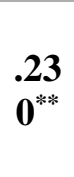 & 1 & $\begin{array}{c}- \\
.07 \\
5-\end{array}$ & $\begin{array}{c}.11 \\
2\end{array}$ & $\begin{array}{c}.07 \\
2\end{array}$ & .21 & $\begin{array}{l}.39 \\
4^{* *}\end{array}$ & $\begin{array}{l}.26 \\
5^{* * *}\end{array}$ & $\begin{array}{l}.29 \\
5^{* * *}\end{array}$ & $.189^{*}$ & $.424^{* * *}$ \\
\hline & $\begin{array}{l}\text { Sig. (2- } \\
\text { tailed) }\end{array}$ & $\begin{array}{c}.00 \\
3\end{array}$ & $\begin{array}{c}.00 \\
2\end{array}$ & & $\begin{array}{c}.31 \\
0\end{array}$ & $\begin{array}{c}.12 \\
9\end{array}$ & $\begin{array}{c}.33 \\
\mathbf{3}\end{array}$ & $\begin{array}{c}.00 \\
4\end{array}$ & $\begin{array}{c}.00 \\
0\end{array}$ & $\begin{array}{c}.00 \\
0\end{array}$ & $\begin{array}{c}.00 \\
0\end{array}$ & .010 & .000 \\
\hline & $\mathbf{N}$ & $\begin{array}{c}18 \\
4\end{array}$ & $\begin{array}{c}18 \\
4\end{array}$ & 184 & 184 & 184 & 184 & 184 & 184 & 184 & 184 & 184 & 184 \\
\hline \multirow{3}{*}{ Q4 } & $\begin{array}{c}\text { Pearso } \\
\text { n } \\
\text { Correl } \\
\text { ation }\end{array}$ & $\begin{array}{c}.15 \\
6^{*}\end{array}$ & $\begin{array}{c}.03 \\
5\end{array}$ & $\begin{array}{c}.07 \\
5-\end{array}$ & 1 & $\begin{array}{l}.24 \\
5^{* * *}\end{array}$ & $\begin{array}{l}.21 \\
5^{* * *}\end{array}$ & $\begin{array}{c}- \\
.01 \\
4-\end{array}$ & $\begin{array}{l}.38 \\
7^{* *}\end{array}$ & .28 & $\begin{array}{l}.30 \\
6^{* * *}\end{array}$ & .131 & $.244^{* *}$ \\
\hline & $\begin{array}{l}\text { Sig. (2- } \\
\text { tailed) }\end{array}$ & $\begin{array}{c}.03 \\
4\end{array}$ & $\begin{array}{c}.63 \\
6\end{array}$ & $\begin{array}{c}.31 \\
0\end{array}$ & & $\begin{array}{c}.00 \\
1\end{array}$ & $\begin{array}{c}.00 \\
3\end{array}$ & $\begin{array}{c}.85 \\
1\end{array}$ & $\begin{array}{c}.00 \\
0\end{array}$ & $\begin{array}{c}.00 \\
0\end{array}$ & $\begin{array}{c}.00 \\
0\end{array}$ & .076 & .001 \\
\hline & $\mathbf{N}$ & $\begin{array}{c}18 \\
4\end{array}$ & $\begin{array}{c}18 \\
4\end{array}$ & 184 & 184 & 184 & 184 & 184 & 184 & 184 & 184 & 184 & 184 \\
\hline \multirow{3}{*}{ Q5 } & $\begin{array}{c}\text { Pearso } \\
\text { n } \\
\text { Correl } \\
\text { ation }\end{array}$ & $\begin{array}{c}.15 \\
2^{*}\end{array}$ & $\begin{array}{l}.35 \\
4^{* * *}\end{array}$ & $\begin{array}{c}.11 \\
2\end{array}$ & $\begin{array}{l}.24 \\
5^{* *}\end{array}$ & 1 & $\begin{array}{c}.14 \\
1\end{array}$ & $\begin{array}{c}.07 \\
6\end{array}$ & $\begin{array}{l}.55 \\
9^{* *}\end{array}$ & $\begin{array}{l}.34 \\
9^{* * *}\end{array}$ & $\begin{array}{l}.42 \\
3^{* *}\end{array}$ & $.201^{* * *}$ & $.423^{* * *}$ \\
\hline & $\begin{array}{l}\text { Sig. (2- } \\
\text { tailed) }\end{array}$ & $\begin{array}{c}.04 \\
0\end{array}$ & $\begin{array}{c}.00 \\
0\end{array}$ & $\begin{array}{c}.12 \\
9\end{array}$ & $\begin{array}{c}.00 \\
1\end{array}$ & & $\begin{array}{c}.05 \\
7\end{array}$ & $\begin{array}{c}.30 \\
2\end{array}$ & $\begin{array}{c}.00 \\
0\end{array}$ & $\begin{array}{c}.00 \\
0\end{array}$ & $\begin{array}{c}.00 \\
0\end{array}$ & .006 & .000 \\
\hline & $\mathbf{N}$ & $\begin{array}{c}18 \\
4 \\
\end{array}$ & $\begin{array}{c}18 \\
4 \\
\end{array}$ & 184 & 184 & 184 & 184 & 184 & 184 & 184 & 184 & 184 & 184 \\
\hline \multirow[t]{3}{*}{ Q6 } & $\begin{array}{c}\text { Pearso } \\
\text { n } \\
\text { Correl } \\
\text { ation } \\
\end{array}$ & $\begin{array}{l}.22 \\
1^{* * *}\end{array}$ & $\begin{array}{l}.15 \\
1^{*}\end{array}$ & $\begin{array}{c}.07 \\
2\end{array}$ & .21 & $\begin{array}{c}.14 \\
1\end{array}$ & 1 & $\begin{array}{c}.10 \\
7\end{array}$ & $\begin{array}{l}.52 \\
6^{* *}\end{array}$ & $\begin{array}{r}.35 \\
8^{* * *}\end{array}$ & .24 & $.147^{*}$ & $.223^{* * *}$ \\
\hline & $\begin{array}{l}\text { Sig. (2- } \\
\text { tailed) }\end{array}$ & $\begin{array}{c}.00 \\
3 \\
\end{array}$ & $\begin{array}{c}.04 \\
0\end{array}$ & $\begin{array}{c}.33 \\
\mathbf{3} \\
\end{array}$ & $\begin{array}{c}.00 \\
3\end{array}$ & $\begin{array}{c}.05 \\
7 \\
\end{array}$ & & $\begin{array}{c}.14 \\
8\end{array}$ & $\begin{array}{c}.00 \\
0\end{array}$ & $\begin{array}{c}.00 \\
0\end{array}$ & $\begin{array}{c}.00 \\
1 \\
\end{array}$ & .046 & .002 \\
\hline & $\mathbf{N}$ & $\begin{array}{c}18 \\
4\end{array}$ & $\begin{array}{c}18 \\
4\end{array}$ & 184 & 184 & 184 & 184 & 184 & 184 & 184 & 184 & 184 & 184 \\
\hline \multirow{3}{*}{ Q7 } & $\begin{array}{c}\text { Pearso } \\
\text { n } \\
\text { Correl } \\
\text { ation }\end{array}$ & $\begin{array}{l}.19 \\
7^{* * *}\end{array}$ & .29 & .21 & $\begin{array}{c}.01 \\
4-\end{array}$ & $\begin{array}{c}.07 \\
6\end{array}$ & $\begin{array}{c}.10 \\
7\end{array}$ & 1 & $\begin{array}{l}.49 \\
3^{* *}\end{array}$ & $\begin{array}{l}.39 \\
4^{* * *}\end{array}$ & $\begin{array}{l}.33 \\
4^{* *}\end{array}$ & -.014- & $.334^{* *}$ \\
\hline & $\begin{array}{l}\text { Sig. (2- } \\
\text { tailed) }\end{array}$ & $\begin{array}{c}.00 \\
7\end{array}$ & $\begin{array}{c}.00 \\
0\end{array}$ & $\begin{array}{c}.00 \\
4\end{array}$ & $\begin{array}{c}.85 \\
1\end{array}$ & $\begin{array}{c}.30 \\
2\end{array}$ & $\begin{array}{c}.14 \\
8\end{array}$ & & $\begin{array}{c}.00 \\
0\end{array}$ & $\begin{array}{c}.00 \\
0\end{array}$ & $\begin{array}{c}.00 \\
0\end{array}$ & .847 & .000 \\
\hline & $\mathbf{N}$ & $\begin{array}{c}18 \\
4\end{array}$ & $\begin{array}{c}18 \\
4 \\
\end{array}$ & 184 & 184 & 184 & 184 & 184 & 184 & 184 & 184 & 184 & 184 \\
\hline \multirow{3}{*}{ Q8 } & $\begin{array}{c}\text { Pearso } \\
\text { n } \\
\text { Correl } \\
\text { ation }\end{array}$ & $\begin{array}{l}.44 \\
2^{* *}\end{array}$ & $\begin{array}{l}.59 \\
4^{* *}\end{array}$ & $\begin{array}{l}.39 \\
4^{* *}\end{array}$ & $\begin{array}{l}.38 \\
7^{* *}\end{array}$ & $\begin{array}{l}.55 \\
9^{* * *}\end{array}$ & $\begin{array}{r}.52 \\
6^{* * *}\end{array}$ & $\begin{array}{l}.49 \\
3^{* * *}\end{array}$ & 1 & $\begin{array}{l}.68 \\
1^{* * *}\end{array}$ & $\begin{array}{l}.62 \\
4^{* *}\end{array}$ & $.355^{* *}$ & $.649^{* * *}$ \\
\hline & $\begin{array}{l}\text { Sig. (2- } \\
\text { tailed) }\end{array}$ & $\begin{array}{c}.00 \\
0\end{array}$ & $\begin{array}{c}.00 \\
0\end{array}$ & $\begin{array}{c}.00 \\
0\end{array}$ & $\begin{array}{c}.00 \\
0\end{array}$ & $\begin{array}{c}.00 \\
0\end{array}$ & $\begin{array}{c}.00 \\
0\end{array}$ & $\begin{array}{c}.00 \\
0\end{array}$ & & $\begin{array}{c}.00 \\
0\end{array}$ & $\begin{array}{c}.00 \\
0\end{array}$ & .000 & .000 \\
\hline & $\mathbf{N}$ & $\begin{array}{c}18 \\
4\end{array}$ & $\begin{array}{c}18 \\
4\end{array}$ & 184 & 184 & 184 & 184 & 184 & 184 & 184 & 184 & 184 & 184 \\
\hline
\end{tabular}




\begin{tabular}{|c|c|c|c|c|c|c|c|c|c|c|c|c|c|}
\hline \multirow{3}{*}{ Q9 } & $\begin{array}{c}\text { Pearso } \\
\text { n } \\
\text { Correl } \\
\text { ation }\end{array}$ & $\begin{array}{l}.36 \\
1^{* * *}\end{array}$ & .33 & .26 & .28 & .34 & 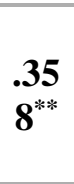 & .39 & $\begin{array}{l}.68 \\
1^{* *}\end{array}$ & 1 & $\begin{array}{l}.65 \\
5^{* *}\end{array}$ & .114 & $.669^{* * *}$ \\
\hline & $\begin{array}{l}\text { Sig. (2- } \\
\text { tailed) }\end{array}$ & $\begin{array}{c}.00 \\
0\end{array}$ & $\begin{array}{c}.00 \\
0\end{array}$ & $\begin{array}{c}.00 \\
0\end{array}$ & $\begin{array}{c}.00 \\
0\end{array}$ & $\begin{array}{c}.00 \\
0\end{array}$ & $\begin{array}{c}.00 \\
0\end{array}$ & $\begin{array}{c}.00 \\
0\end{array}$ & $\begin{array}{c}.00 \\
0\end{array}$ & & $\begin{array}{c}.00 \\
0\end{array}$ & .122 & .000 \\
\hline & $\mathbf{N}$ & $\begin{array}{c}18 \\
4\end{array}$ & $\begin{array}{c}18 \\
4\end{array}$ & 184 & 184 & 184 & 184 & 184 & 184 & 184 & 184 & 184 & 184 \\
\hline \multirow[t]{3}{*}{ Q10 } & $\begin{array}{c}\text { Pearso } \\
\mathbf{n} \\
\text { Correl } \\
\text { ation }\end{array}$ & .36 & .36 & .29 & .30 & .42 & .24 & $\begin{array}{l}.33 \\
4^{* *}\end{array}$ & $\begin{array}{l}.62 \\
4^{* *}\end{array}$ & $\begin{array}{l}.65 \\
5^{* *}\end{array}$ & 1 &. $\mathbf{3 0 1}^{* * *}$ & $.654^{* * *}$ \\
\hline & $\begin{array}{l}\text { Sig. (2- } \\
\text { tailed) }\end{array}$ & $\begin{array}{c}.00 \\
0\end{array}$ & $\begin{array}{c}.00 \\
0\end{array}$ & $\begin{array}{c}.00 \\
0\end{array}$ & $\begin{array}{c}.00 \\
0\end{array}$ & $\begin{array}{c}.00 \\
0\end{array}$ & $\begin{array}{c}.00 \\
1\end{array}$ & $\begin{array}{c}.00 \\
0\end{array}$ & $\begin{array}{c}.00 \\
0\end{array}$ & $\begin{array}{c}.00 \\
0\end{array}$ & & .000 & .000 \\
\hline & $\mathbf{N}$ & $\begin{array}{c}18 \\
4\end{array}$ & $\begin{array}{c}18 \\
4\end{array}$ & 184 & 184 & 184 & 184 & 184 & 184 & 184 & 184 & 184 & 184 \\
\hline \multirow{3}{*}{$\begin{array}{c}\text { Integrat } \\
\text { ed } \\
\text { disclosur } \\
\text { e }\end{array}$} & $\begin{array}{c}\text { Pearso } \\
\mathbf{n} \\
\text { Correl } \\
\text { ation }\end{array}$ & $\begin{array}{l}.23 \\
2^{* *}\end{array}$ & .19 & $\begin{array}{c}.18 \\
9^{*}\end{array}$ & $\begin{array}{c}.13 \\
1\end{array}$ & $\begin{array}{l}.20 \\
1^{* * *}\end{array}$ & $\begin{array}{l}.14 \\
7^{*}\end{array}$ & $\begin{array}{c}- \\
.01 \\
4-\end{array}$ & $\begin{array}{l}.35 \\
5^{* *}\end{array}$ & $\begin{array}{c}.11 \\
4\end{array}$ & $\begin{array}{l}.30 \\
1^{* * *}\end{array}$ & 1 & $.191^{* *}$ \\
\hline & $\begin{array}{l}\text { Sig. (2- } \\
\text { tailed) }\end{array}$ & $\begin{array}{c}.00 \\
2\end{array}$ & $\begin{array}{c}.00 \\
8\end{array}$ & $\begin{array}{c}.01 \\
0\end{array}$ & $\begin{array}{c}.07 \\
6 \\
\end{array}$ & $\begin{array}{c}.00 \\
6 \\
\end{array}$ & $\begin{array}{c}.04 \\
6\end{array}$ & $\begin{array}{c}.84 \\
7 \\
\end{array}$ & $\begin{array}{c}.00 \\
0\end{array}$ & $\begin{array}{c}.12 \\
2\end{array}$ & $\begin{array}{c}.00 \\
0\end{array}$ & & .009 \\
\hline & $\mathbf{N}$ & $\begin{array}{c}18 \\
4\end{array}$ & $\begin{array}{c}18 \\
4\end{array}$ & 184 & 184 & 184 & 184 & 184 & 184 & 184 & 184 & 184 & 184 \\
\hline \multirow{3}{*}{$\begin{array}{c}\text { social } \\
\text { responsi } \\
\text { bility }\end{array}$} & $\begin{array}{c}\text { Pearso } \\
\text { n } \\
\text { Correl } \\
\text { ation }\end{array}$ & .37 & $\begin{array}{l}.49 \\
9^{* *}\end{array}$ & $4^{* * *}$ & .24 & $\begin{array}{l}.42 \\
3^{* *}\end{array}$ & .22 & .33 & $\begin{array}{l}.64 \\
9^{* * *}\end{array}$ & .66 & $\begin{array}{l}.65 \\
4^{* *}\end{array}$ & $.191^{* *}$ & 1 \\
\hline & $\begin{array}{l}\text { Sig. (2- } \\
\text { tailed) }\end{array}$ & $\begin{array}{c}.00 \\
0\end{array}$ & $\begin{array}{c}.00 \\
0\end{array}$ & $\begin{array}{c}.00 \\
0\end{array}$ & $\begin{array}{c}.00 \\
1\end{array}$ & $\begin{array}{c}.00 \\
0\end{array}$ & $\begin{array}{c}.00 \\
2\end{array}$ & $\begin{array}{c}.00 \\
0\end{array}$ & $\begin{array}{c}.00 \\
0\end{array}$ & $\begin{array}{c}.00 \\
0\end{array}$ & $\begin{array}{c}.00 \\
0\end{array}$ & .009 & \\
\hline & $\mathbf{N}$ & $\begin{array}{c}18 \\
4\end{array}$ & $\begin{array}{c}18 \\
4\end{array}$ & 184 & 184 & 184 & 184 & 184 & 184 & 184 & 184 & 184 & 184 \\
\hline
\end{tabular}

**. Correlation is significant at the 0.01 level (2-tailed).

*. Correlation is significant at the 0.05 level (2-tailed).

Table No. (7) shows the correlation coefficient for the axes paragraphs, and we note from the results received that the correlation coefficients indicate a strong positive correlation, and it is statistically significant at the level of significance (0.05) in terms of P.Value (0.000), as it is inferred from the results that the possibility of Modifying the moral relationship with a degree of freedom (0.01) as a result of the strength of the correlation reflected in the results, and as a result, the measurement tool has high credibility, and then indicates clear agreement in the answers of the research sample, which amounted to (184) respondents, about the questionnaire items for the study variables, and the result Therefore, the validity of the first and second hypotheses was confirmed, which states that there is a statistically significant relationship between management assurances, the quality of integrated disclosure and the social responsibility of the organization.

To approve the validity of the third hypothesis, which states (that the business environment is affected by the diversity of the board of directors and the disclosure and social responsibility of the organization), Table No. (8) shows the relationship between the axis of diversity of the board of directors and integrated disclosure and social responsibility, as well as the business environment, where it follows: 
Table (8) Correlations

(Business environment, diversity of the board of directors, integrated disclosure, social responsibility)

\begin{tabular}{|c|c|c|c|c|c|}
\hline & & $\begin{array}{c}\text { business } \\
\text { environment }\end{array}$ & $\begin{array}{c}\text { Diversity } \\
\text { of the } \\
\text { board }\end{array}$ & $\begin{array}{l}\text { Integrated } \\
\text { disclosure }\end{array}$ & $\begin{array}{c}\text { Social } \\
\text { Responsibility }\end{array}$ \\
\hline \multirow{3}{*}{$\begin{array}{c}\text { business } \\
\text { environment }\end{array}$} & $\begin{array}{c}\text { Pearson } \\
\text { Correlation }\end{array}$ & 1 & $.178^{*}$ & $.355^{* *}$ & $.649^{* *}$ \\
\hline & $\begin{array}{c}\text { Sig. }(2- \\
\text { tailed) }\end{array}$ & & .016 & .000 & .000 \\
\hline & $\mathbf{N}$ & 184 & 184 & 184 & 184 \\
\hline \multirow{3}{*}{$\begin{array}{l}\text { Diversity of the } \\
\text { board }\end{array}$} & $\begin{array}{c}\text { Pearson } \\
\text { Correlation }\end{array}$ & $.178^{*}$ & 1 & $-.070-$ & $.312^{* *}$ \\
\hline & $\begin{array}{l}\text { Sig. (2- } \\
\text { tailed) }\end{array}$ & .016 & & .343 & .000 \\
\hline & $\mathbf{N}$ & 184 & 184 & 184 & 184 \\
\hline \multirow{3}{*}{$\begin{array}{l}\text { Integrated } \\
\text { disclosure }\end{array}$} & $\begin{array}{c}\text { Pearson } \\
\text { Correlation }\end{array}$ & $.355^{* *}$ & $-.070-$ & 1 & $.191^{* *}$ \\
\hline & $\begin{array}{c}\text { Sig. (2- } \\
\text { tailed) }\end{array}$ & .000 & .343 & & .009 \\
\hline & $\mathbf{N}$ & 184 & 184 & 184 & 184 \\
\hline \multirow{3}{*}{$\begin{array}{c}\text { Social } \\
\text { Responsibility }\end{array}$} & $\begin{array}{c}\text { Pearson } \\
\text { Correlation }\end{array}$ & $.649^{* *}$ & $.312^{* *}$ & $.191^{* *}$ & 1 \\
\hline & $\begin{array}{l}\text { Sig. }(2- \\
\text { tailed) }\end{array}$ & .000 & .000 & .009 & \\
\hline & $\mathbf{N}$ & 184 & 184 & 184 & 184 \\
\hline
\end{tabular}

To confirm the validity of the hypotheses, Table (8) presents the degree of influence and the correlation between the total variables

\section{Discussion}

That the organization is part of a social environment, representing its business environment. Affect and are affected by the values of that society or what is known as cultural dimensions, which can be of a sensitive nature, in integrated reporting practices and as a result its reflection on the market value. The results show that the diversity of the board of directors is an important factor in integrated disclosure, and in strengthening the social responsibility of the organization towards stakeholders. Because of the nature of the composition of the social personality of those responsible for the preparation of reports. In addition to the above, the business environment, in which administrative and investment decisions are made, has an impact on the nature of the behaviors and directions that the decision-maker can adopt. 
Culture is a factor affecting human behavior in particular and society in general, and its values in general, and cannot be neglected or dispensed with, in the formation of personal or social and economic practices, and as a result, its impact on accounting practices cannot be neglected as it is part of society, it affects and is affected by cultural behaviors that reflect Personal characteristics of stakeholders. Societies are usually classified according to cultural concepts that reflect the level of awareness, development, and adherence to societal customs and values.

\section{Recommendations}

Understanding how a person's mindset or behavior affects the success or failure of a business environment in achieving its goals is important to helping an organization manage its resources. more effectively and reduce potential unwanted cultural biases. that can affect the course of decision-making. As the organizational culture of the administration can affect the level of performance improvement and the effectiveness of communication at the organizational and personal level with workers or beneficiaries of its outputs, whether services or data intended for use in decision-making. In general, promoting integrated disclosure and social responsibility. Aims to fundamentally change the way we manage and report to stakeholders for decision making.

By establishing relationships between the organization's elements, productivity, administrative and other functions. And linking it with the elements of capital that use or influence them, to provide a long-term vision, and part of the prevailing practices in the economic business environment, which leads to the allocation of capital efficiently and productivity, and support financial stability

\section{Reference:}

[1] Adedeji, B, S, Popoola, O, M, J,, \& San Ong, T, (2017), National culture and sustainability disclosure practices: A literature review, Indian-Pacific Journal of Accounting and Finance, 1(1), 26-50.

[2] Adger, W, N, Barnett, J,, Brown, K,, Marshall, N,, \& O'Brien, K, (2013), Cultural dimensions of climate change impacts and adaptation, Nature climate change, 3(2), 112-117.

[3] Dabić, M,, Tipurić, D, \& Podrug, N, (2015), Cultural differences affecting decisionmaking style: a comparative study between four countries, Journal of Business Economics and Management, 16(2), 275-289.

[4] Durak, M. G. (2013). Factors affecting the companies' preferences on integrated reporting. International Journal of Contemporary Economics and Administrative Sciences, 3(3-4), 68-85.

[5] Fink, G, Neyer, A, K, \& Kölling, M, (2006), Understanding cross-cultural management interaction: Research into cultural standards to complement cultural value dimensions and personality traits, International Studies of Management \& Organization, 36(4), 38-60.

[6] Ford, G, \& Kotzé, P, (2005, September), Designing usable interfaces with cultural dimensions, In IFIP Conference on Human-Computer Interaction, Springer, Berlin, Heidelberg, (pp, 713-726).

[7] Gerwanski, J., Kordsachia, O., \& Velte, P. (2019). Determinants of materiality disclosure quality in integrated reporting: Empirical evidence from an international setting. Business Strategy and the Environment, 28(5), 750-770.

[8] Glazer, S., Karpati, T., (2014), The Role of Culture in Decision Making, Cutter It Journal, Vol. 27, p. 9, p. 23-29.

[9] Hall, E,T, and M,R, Hall, 1990, Understanding Cultural Differences: Keys to Success in West Germany, France and the United States, Yarmouth, ME: Intercultural Press. 
[10] Hofstede, G, (1983), National cultures in four dimensions: A research-based theory of cultural differences among nations, International Studies of Management \& Organization, 13(1-2), 46-74.

[11] Hofstede, G, (2011), Dimensional zing Cultures: The Hofstede Model in Context, Online Readings in Psychology and Culture, Unit 2, Retrieved from http://scholarworks, gvsu,edu/orpc/vol2/iss 1/8.

[12] Hunt, S, D, \& Vitell, S, (1986), A general theory of marketing ethics, Journal of macro marketing, 6(1), 5-16.

[13] Leng, C. Y., \& Botelho, D. (2010). How does national culture impact on consumers' decision-making styles? A cross cultural study in Brazil, the United States and Japan. BAR-Brazilian Administration Review, 7, 260-275.

[14] Mavin, S., \& Grandy, G. (2016). Women elite leaders doing respectable business femininity: How privilege is conferred, contested and defended through the body. Gender, Work \& Organization, 23(4), 379-396.

[15] Podrug, N,, Pavičić, J,, \& Bratić, V, (2006), Cross-cultural comparison of Hofstede's dimensions and decision-making style within CEE context, In From transition to sustainable development: The path to European integration, 1-16.

[16] Polletta, F, (1997), Culture and its discontents: Recent theorizing on the cultural dimensions of protest, Sociological Inquiry, 67(4), 431-450.

[17] Vitell, S, J, Nwachukwu, S, L, \& Barnes, J, H, (1993), The effects of culture on ethical decision-making: An application of Hofstede's typology, Journal of business Ethics, 12(10), 753-760.

[18] Warner-Søderholm, G, (2013), Beyond a Literature Review of Hall's Context Dimension: Scale Development, Validation \& Empirical Findings Within a Norwegian Study, International Journal of Business and Management; Vol, 8, No, 10, 27-40.

[19] Waterstraat, Silke Kalra (2015), Cultural Significance on Accounting: Analyzing the Link between Uncertainty Avoidance and Accounting Conservatism in the HofstedeGray-Framework, of the University of St, Galen. 